\title{
Carcass and meat traits of feedlot Nellore bulls fed different dietary energy sources
}

\author{
Geraldo Helber Batista Maia Filho', Fabiano Alvim Barbosa ${ }^{2}$, Lucas Luz Emerick', Rafahel \\ Carvalho Souza ${ }^{3}$, Tadeu Chaves Figueiredo ${ }^{4}$, Henrique de Oliveira Azevedo ${ }^{5}$, Luigi Francis \\ Lima Cavalcanti, ${ }^{6,7}$, Raphael Amazonas Mandarino ${ }^{1}$
}

\footnotetext{
${ }^{1}$ Universidade Federal de Minas Gerais, Escola de Veterinária, Programa de Pós-graduação em Zootecnia, Belo Horizonte, MG, Brazil.

${ }^{2}$ Universidade Federal de Minas Gerais, Escola de Veterinária, Departamento de Zootecnia, Belo Horizonte, MG, Brazil.

${ }^{3}$ Pontifíicia Universidade Católica de Minas Gerais, Departamento de Medicina Veterinária, Belo Horizonte, MG, Brazil.

${ }^{4}$ Universidade Federal de Minas Gerais, Escola de Veterinária, Departamento de Tecnologia e Inspeção de Produtos de Origem Animal, Belo Horizonte, MG, Brazil.

${ }^{5}$ Pecuária Sustentável da Amazônia S.A., Alta Floresta, MT, Brazil.

${ }^{6}$ Seva Engenharia - Intergado, Belo Horizonte, MG, Brazil.

${ }^{7} \mathrm{CNPq} / \mathrm{RHAE}$ fellowship recipient.
}

\begin{abstract}
The objective of this experimental study was to evaluate the effects of different dietary energy sources on the carcass and meat traits of feedlot Nellore bulls. A total of 48 Nellore bulls at 32 months of age with $354.35 \pm 19.56 \mathrm{~kg}$ body weight were studied for 85 days. The bulls were allotted to four groups of 12 individuals: Whole corn grain - diet based on whole corn grain; Ground corn - diet based on ground corn grain; Citrus pulp - diet based on citrus pulp; and Steam-flaked corn - diet based on steam-flaked corn. Diets did not influence carcass quality or meat quality. Average values for fat depth, rib eye area, shear force, total cooking losses, and carcass yield were $4.97 \mathrm{~mm}, 74.71 \mathrm{~cm}^{2}, 5.85 \mathrm{kgf}, 26.82 \%$, and $52.0 \%$, respectively. Based on the quantitative and qualitative analysis of this study, there is no restriction for the adoption of any of the tested diets in feedlots with Nellore bulls and the evaluated energy sources may be used to replace ground corn grain.
\end{abstract}

Key Words: fat, high-concentrate diets, intake, rib eye area, tenderness

\section{Introduction}

Feed accounts for most of the production costs in feedlot systems. Feeding programs are based on studies aimed at understanding with greater accuracy the interactions and impacts generated by using high levels of concentrate of various sources on cattle feeding. Animals fed high amounts of concentrate may have a faster growth rate, which will benefit qualitative traits, including tenderness, because they reach the point of slaughter sooner (Costa et al., 2005). Among the variables of the high cost of feeding, the energy source is almost dependent on corn. By contrast, corn is valued in the feeding of monogastric animals. Thus, the viability of replacing corn by another energy source would contribute to reducing feed costs for feedlot cattle.

Received September 4, 2015 and accepted February 12, 2016.

Corresponding author: fabianoalvimvet@hotmail.com

http://dx.doi.org/10.1590/S1806-92902016000500009

Copyright () 2016 Sociedade Brasileira de Zootecnia. This is an Open Access article distributed under the terms of the Creative Commons Attribution License (http://creativecommons.org/licenses/by/4.0/), which permits unrestricted use, distribution, and reproduction in any medium, provided the original work is properly cited.
The forage production and distribution logistics is a major complicating constraint in the large scale. Therefore, strategies with high-concentrate diets can reduce the need for production and distribution of roughage. This type of feed, besides having advantages such as decreased finishing time greater feed efficiency, facilitates transport, storage, mixing, and distribution of the diet (Paulino et al., 2013). The use of foods like citrus pulp, soybean hulls, pellets, and even whole-grain corn can be cost-effective alternatives to standard foods, which are partly responsible for the high production costs of feedlots.

The study of different dietary ratios of concentrate to ingredients is crucial because it facilitates the determination of the optimal feed level to obtain the best animal performance coupled with the best economic return (Costa et al., 2005), thus resulting in higher carcass yield with adequate fatness and better meat quality.

Diets with whole corn grain and pelleted supplement have been used in recently Brazil and provided satisfactory animal performance, but the carcass and meat quality was not assessed (Mandarino et al., 2013). The objective of this experiment was to evaluate the effect of different energy sources in the diet on carcass and meat quality of Nellore bulls. 


\section{Material and Methods}

All the experimental procedures in this study are in accordance with the Ethical Principles of Animal Experimentation adopted by the Ethics Committee on Animal Use of Universidade Federal de Minas Gerais (CEUA/UFMG) (no. 155/2012).

The experimental period lasted 85 days, from July to October 2013. A group of 48 Nellore bulls were used with an average age of $32 \pm 1$ months and an average weight of $354.35 \pm 19.56 \mathrm{~kg}$ at the beginning of the experiment.

The animals were allocated to a feedlot consisting of 16 pens measuring $60 \mathrm{~m}^{2}$ each, with three animals per pen. All pens were equipped with a drinker, a trough for mineral supply, and a trough for feed supply.

The 48 animals were randomly assigned into four treatments, resulting in 12 animals per group. Each lot was fed a diet (Table 1) formulated to provide an average daily weight gain of $1.3 \mathrm{~kg}$ according to the nutritional requirements described by Marcondes et al. (2010). The following treatments were applied: Whole corn grain - diet consisting of whole-grain corn and commercial pelleted supplement; Ground corn - diet consisting of Pennisetum purpureum silage and ground corn grain as the main ingredient in concentrate; Citrus pulp - diet consisting of Pennisetum purpureum silage and citrus pulp as the main feed in concentrate; Steam-flaked corn - diet consisting of Pennisetum purpureum silage and steam-flaked corn as the main ingredient in concentrate.

Animals underwent a 21-day period of adaptation to the feedlot, during which they were fed a total mixed diet in the amount of $1.8 \%$ of their live weight (dry matter basis) consisting of grass silage as a roughage source and concentrate feed based on ground corn, soybean meal, urea, and minerals. Roughage:concentrate ratios (R:C) of 60:40 on a total dry matter basis were used in the adaptation period, and the amount of concentrate was increased gradually to reach $00: 100,31: 69,27: 75$, and $32: 68$ (R:C) for Whole corn grain, Ground corn, Citrus pulp, and Steamflaked corn treatments, respectively, in the final period of adaptation. Following this period, the diets were provided ad libitum, split into three daily supplies, at $08.00 \mathrm{~h}, 11.00 \mathrm{~h}$, and $15.00 \mathrm{~h}$. The amount of feed provided was adjusted daily to allow for leftovers of approximately $5-10 \%$ of the offered feed. The amount of feed provided was adjusted daily, based on the intake observed on the previous day, and the leftovers were weighed daily. Feed and leftover samples were collected, weighed and placed in properly labeled plastic bags. The weekly composite samples of leftovers and silage were dried in a forced-air oven at $65{ }^{\circ} \mathrm{C}$ for $72 \mathrm{~h}$ and then ground in a mill with a one-millimeter sieve. Following the milling, the leftover samples from each pen from two consecutive weeks were weighed and homogenized, making a composite sample for each 14-day period. Therefore, five composite samples of leftovers from each pen were prepared. The levels of dry matter (DM), ash, crude protein (CP), and ether extract (EE) in composite samples of leftovers, silage, and concentrate ingredients were quantified (AOAC, 1990). Neutral detergent fiber (NDF) levels were determined according to protocols described by Van Soest et al. (1991) and Licitra et al. (1996). Acid detergent fiber (ADF) and lignin levels were obtained using the fractionation method described by Licitra et al. (1996). Non-fibrous carbohydrates (NFC) were calculated according to the National Research Council (NRC) (2001), as follows:

$\mathrm{NFC}(\%)=100-(\% \mathrm{NDF}+(\% \mathrm{CP}-\% \mathrm{NDIP})+\% \mathrm{EE}+\%$ ash $)$,

Table 1 - Ratio of ingredients and nutritional composition of diets $(\%)$, on a dry matter basis

\begin{tabular}{|c|c|c|c|c|}
\hline \multirow[b]{2}{*}{ Ingredient } & \multicolumn{4}{|c|}{ Diet } \\
\hline & $\begin{array}{l}\text { Whole } \\
\text { corn grain }\end{array}$ & $\begin{array}{l}\text { Ground } \\
\text { corn }\end{array}$ & $\begin{array}{l}\text { Citrus } \\
\text { pulp }\end{array}$ & $\begin{array}{c}\text { Steam-flaked } \\
\text { corn }\end{array}$ \\
\hline Whole corn grain & 85.00 & - & - & - \\
\hline $\begin{array}{l}\text { Commercial pelleted } \\
\text { supplement }^{1}\end{array}$ & 15.00 & - & - & - \\
\hline $\begin{array}{l}\text { Pennisetum purpureum } \\
\text { silage }\end{array}$ & - & 31.00 & 25.00 & 38.00 \\
\hline Ground corn & - & 61.00 & 10.80 & - \\
\hline Steam-flaked corn & - & - & - & 51.00 \\
\hline Citrus pulp & - & - & 50.00 & - \\
\hline Soybean meal & - & 5.00 & 12.00 & 8.00 \\
\hline Mineral premix ${ }^{2}$ & - & 1.20 & 1.20 & 1.20 \\
\hline Limestone & - & 0.80 & - & 0.80 \\
\hline Urea & - & 1.00 & 1.00 & 1.00 \\
\hline Total & 100.00 & 100.00 & 100.00 & 100.00 \\
\hline Dry matter & 84.63 & 49.69 & 54.37 & 46.71 \\
\hline Crude protein $(\mathrm{CP})$ & 14.14 & 12.00 & 13.45 & 12.24 \\
\hline NDF & 9.71 & 32.12 & 36.54 & 37.00 \\
\hline $\mathrm{ADF}$ & 4.60 & 17.38 & 27.28 & 19.64 \\
\hline Lignin & 1.98 & 2.80 & 7.82 & 2.47 \\
\hline Starch & 60.89 & 43.23 & 2.72 & 38.63 \\
\hline Ether extract & 2.23 & 3.17 & 1.54 & 2.94 \\
\hline Ash & 3.46 & 5.36 & 7.57 & 5.89 \\
\hline NFC & 71.91 & 48.98 & 42.70 & 43.65 \\
\hline TDN & 85.48 & 69.87 & 70.14 & 72.66 \\
\hline $\mathrm{ME}, \mathrm{Mcal} / \mathrm{kg}$ & 3.35 & 2.66 & 2.67 & 2.78 \\
\hline
\end{tabular}

Whole corn grain - diet consisting of whole-grain corn and commercial pelleted supplement; Ground corn - diet consisting of Pennisetum purpureum silage and ground corn grain as the main ingredient in concentrate; Citrus pulp - diet consisting of Pennisetum purpureum silage and citrus pulp as the main feed in concentrate; Steam-flaked corn - diet consisting of Pennisetum purpureum silage and steamflaked corn as the main ingredient in concentrate.

NDF - neutral detergent fiber; ADF - acid detergent fiber; NFC - non-fibrous carbohydrate; TDN - total digestible nutrients; $\mathrm{ME}$ - metabolizable energy $=(1.01 \times$ $0.04409 \times \mathrm{TDN})-0.45$, according to NRC $(2001)$.

${ }^{1}$ Containing 11 g/kg P; 26 g/kg Ca; 11 g/kg S; 8 g/kg Mg; 6 g/kg Na; 350 mg/kg Zn; $100 \mathrm{mg} / \mathrm{kg} \mathrm{Cu} ; 300 \mathrm{mg} / \mathrm{kg} \mathrm{Fe} ; 312 \mathrm{mg} / \mathrm{kg} \mathrm{Mn} ; 4 \mathrm{mg} / \mathrm{kg} \mathrm{Co} ; 6 \mathrm{mg} / \mathrm{kg} \mathrm{I} ; 2 \mathrm{mg} / \mathrm{kg} \mathrm{Se}$; $37.3 \% \mathrm{CP} ; 66.4 \% \mathrm{TDN}$.

${ }^{2}$ Containing $54 \mathrm{~g} / \mathrm{kg} \mathrm{P} ; 175 \mathrm{~g} / \mathrm{kg} \mathrm{Ca} ; 23 \mathrm{~g} / \mathrm{kg} \mathrm{S} ; 9$ g/kg Mg; $111 \mathrm{~g} / \mathrm{kg} \mathrm{Na} ; 2,450 \mathrm{mg} / \mathrm{kg}$ $\mathrm{Zn} ; 875 \mathrm{mg} / \mathrm{kg} \mathrm{Cu} ; 1,500 \mathrm{mg} / \mathrm{kg} \mathrm{Fe} ; 520 \mathrm{mg} / \mathrm{kg} \mathrm{Mn} ; 46 \mathrm{mg} / \mathrm{kg} \mathrm{Co} ; 47 \mathrm{mg} / \mathrm{kg} \mathrm{I}$; $16 \mathrm{mg} / \mathrm{kg} \mathrm{Se} ; 15 \mathrm{mg} / \mathrm{kg} \mathrm{Cr} ; 1,700 \mathrm{mg} / \mathrm{kg}$ virginiamycin; $1,700 \mathrm{mg} / \mathrm{kg}$ monensin. 
in which NDIP = average neutral detergent insoluble protein. The dietary energy density, expressed as total digestible nutrients (TDN), was estimated using the formula recommended by Capelle et al. (2001): TDN (\%) =91.0246 $-0.571588 \times \mathrm{NDF}$. The ruminal degradability values of dry matter and NDF of the feeds were estimated using the nylon bag method (Mehrez and Orskov, 1977).

The animals were weighed at the beginning of the experimental period and every 28 days, after a 14-h food and water fasting period, to assess the animal performance variables, including the initial live weight (ILW), final live weight (FLW), average daily gain (ADG), and average daily gain relative to the eviscerated and hot carcass weight (CADG; kg), defined as carcass adjusted performance (Buttrey et al., 2012). The ADG was calculated as the difference between FLW and ILW, divided by the number of days in the feedlot. The CADG was calculated as the difference between the eviscerated and hot carcass weight on the day of slaughter and the initial weight, divided by two. The result of this difference was divided by the number of days in the feedlot.

All animals were slaughtered $24 \mathrm{~h}$ after the last experimental day. Animals were weighed in the morning before they were sent to the slaughterhouse. At the slaughterhouse, animals were deprived of solids for $24 \mathrm{~h}$, with water intake ad libitum. All animals were euthanized by brain concussion, followed by sectioning of the external jugular vein, according to the regulations established by the Brazilian Ministry of Agriculture, Livestock and Food Supply (Freitas et al., 2001).

The hot and cold carcasses were weighed at the slaughterhouse to calculate the respective yields of the carcasses and their cuts. The carcass cuts were divided into hindquarter, forequarter, and spare ribs (Yokoo et al., 2003). Only the left carcass side was used for measurement of the cuts and the records were multiplied by two to obtain the result for the whole carcass (Sakamoto et al., 2014). The hot carcass yield (CY) was calculated using the following equation: $\mathrm{CY}=$ hot carcass weight $/ \mathrm{FLW} \times 100$.

Fat thickness (FT) at the 12th-13th rib was assessed by measuring the fat thickness around the longissimus thoracis muscle; the average of three points measured at $1 / 4,1 / 2$, and $3 / 4$ of the outer lateral surface of the said muscle was obtained. The rib eye area $\left(\mathrm{REA}, \mathrm{cm}^{2}\right)$ was assessed using a checkered plastic grid placed under the longissimus thoracis to outline the muscle (Boggs and Merkel, 1979; Ribeiro et al., 2008).

A 2.54-cm-thick steak was removed from the longissimus thoracis muscle during deboning, near the 12th rib, and frozen $\left(-20^{\circ} \mathrm{C}\right)$ in a vacuum-sealed package to evaluate the meat quality according to the thawing and cooking weight losses and the meat tenderness according to shear force test (Warner-Bratzler Shear Force). The samples were thawed under refrigeration $\left(2\right.$ to $\left.5{ }^{\circ} \mathrm{C}\right)$ for $36 \mathrm{~h}$, and the thawing losses were assessed after that period by calculating the difference between the weight of the package containing the steak, the weight of the steak alone, and the weight of the clean and dry package.

The sample (steak) and tray and grill set were weighed separately and then the meat was cooked in an electric oven (Makel, Jaraguá, São Paulo, Brazil), preheated and stabilized at $170{ }^{\circ} \mathrm{C}$, to assess the cooking weight losses. The internal temperature of all the samples was monitored during this period using thermocouple sensors attached to a CSC-99 thermometer (Contemp, São Caetano do Sul, São Paulo, Brazil). After the sample reached a temperature of $71{ }^{\circ} \mathrm{C}$ at its geometric center, the tray and grill set containing the sample was removed from the oven, left standing at room temperature for two hours and then reweighed. Sample and the tray and grill set were also weighed individually. Evaporation losses were determined as the difference between the weight of the tray and grill set containing the sample before and after cooking. Drip losses were determined as the difference between the weight of the grill before and after cooking. The total cooking losses were calculated as the difference between the raw and cooked sample.

The samples/steaks were stored under refrigeration ( 2 to $5{ }^{\circ} \mathrm{C}$ ) overnight after weighing, before the start of the shear force assessment. Eight cylinders $1.27 \mathrm{~cm}$ in diameter were removed in parallel to the direction of the muscle fibers and underwent an objective evaluation of tenderness using a TA-XT2 texturometer (Stable Micro Systems, Godalming, Surrey, United Kingdom) coupled to a Warner-Bratzler blade, set at the speed of $200 \mathrm{~mm} / \mathrm{min}$. The average of eight replicates was considered the Warner-Bratzler shear force (WBSF) value of each sample/steak.

All variables were analyzed separately using linear mixed model approach fitted by restricted maximum likelihood, where animal nested within pen effect was included as a random term, with the exception of feed intake, in which, instead of animal, the pen was considered the experimental unit. Thus, only the pen effect was assumed as random. Diet was considered a fixed effect (eq. 1).

$$
Y_{i j k}=\mu+\delta_{i}+r_{j(k)}^{*}+e_{i j k} ; \quad e_{i j k} \sim i i d \mathbb{N}\left(0, \sigma_{i \varepsilon}^{2}\right)
$$

in which $\mathrm{Y}$ is the dependent variable response measured in animal $j$ fed diet $i$ allocated to pen $k ; \mu$ is the overall mean; $\delta$ is the fixed effect of diet; $r$ is the random effect of animal nested within pen; and $e$ is the experimental error. 
When the pen was assumed as the experimental unit, the $r$ term was replaced by $r_{k}$, which implies a random effect of pen.

Any possible heteroscedasticity due to diet was modeled by applying a variance function that allowed different variances for each diet. This weight term was included in the model, since its inclusion implied reduction of Akaike's Information Criterion compared to the homoscedasticity model. Least square means of response variables for the main effect of diet were reported, and compared using Tukey-Kramer test, in which $\mathrm{P}<0.05$ was considered the level for significant differences. All analyses were performed on R software (R Core Team, 2015) using the nlme package (Pinheiro et al., 2013).

\section{Results and Discussion}

The dry matter intake (DMI) of animals treated with the Whole corn grain diet was lower than in the other treatments $(\mathrm{P}<0.05$; Table 2$)$. This pattern was also observed for the dry matter intake as a percentage of the live weight ( $\%$ LW), which averaged 1.77, 2.34, 2.33, and 2.33\% LW in the Whole corn grain, Ground corn, Citrus pulp, and Steam-flaked corn treatments, respectively $(\mathrm{P}=0.00019)$. The physiological mechanism of food-intake regulation consists of limiting intake when the energy requirement of the animal is met (Mertens, 1994). This regulation system is reported in cases in which the food has high palatability, low filling capacity, and high concentrate-to-roughage ratio (Mertens, 1994), most likely similar to the conditions of the present study (Table 1). The diet consisting of whole corn grain had $85.48 \%$ TDN, $60.89 \%$ starch, and $71.91 \%$ NFC (Table 1). The dry matter intake of the whole corn grain-based diet provided an intake of $4.90 \mathrm{~kg} \mathrm{NFC/day,}$ while the Steam-flaked corn, Citrus pulp, and Ground corn diets provided intakes of $4.24,4.03$, and $4.65 \mathrm{~kg} \mathrm{NFC/}$ day, respectively. These values suggest that the energy content of the diet restricted the DMI in the animals fed whole corn grain-based diets, resulting in a DMI below the animal requirements $(8.87 \mathrm{~kg})$ for the gain calculated in the experiment (1.3 kg/animal), leading to decreased intake of other nutrients that affect the animal performance (Marcondes et al., 2010).

The final weight and ADG were lower in the animals treated with the whole corn grain-based $\operatorname{diet}(\mathrm{P}<0.05)$ than in the animals fed the steam-flaked corn- and ground cornbased diets (Table 2). These results may also be explained by the lower DMI of the animals in this treatment (Table 2), resulting in lower crude protein and TDN intakes, which lead to lower animal performance, because the dietary percentage of this nutrient was similar among the diets (Table 1).

The ADG of the steam-flaked corn and ground cornbased treatments was approximately $24.6 \%$ higher, that is, $1.64 \pm 0.14$ and $1.60 \pm 0.30 \mathrm{~kg}$, respectively, than the calculated gain of $1.3 \mathrm{~kg}$. Corn processing increases starch utilization in vitro, in situ, and in vivo as a result of the improved ruminal fermentation and intestinal digestion (Theurer et al., 1999). By contrast, corn milling reduces the particle size, affecting the ruminal fermentation patterns, microbial production, and the ruminal utilization efficiency of starch and other nutrients (Passini et al., 2004). These facts may help to explain the increased ADG compared with the calculated value recorded in this study in the animals fed the steam-flaked corn- and ground corn-based diets (Table 2), indicating improved efficiency of nutrient digestion in these treatments and resulting in greater TDN intake $(7.00 \mathrm{~kg})$, which, in turn, met the nutritional requirement of $1.60 \mathrm{~kg} /$ day gain of TDN, which is $6.82 \mathrm{~kg}$ (Marcondes et al., 2010).

The animals fed the whole corn grain-based diet showed an average DMI of $6.82 \mathrm{~kg} /$ day, with ADG performance of

Table 2 - Predicted means and standard error of the means (in parentheses) for dry matter intake per animal, performance, and carcass characteristics of Nellore bulls

\begin{tabular}{|c|c|c|c|c|c|}
\hline \multirow{2}{*}{ Treatment/Variable } & \multicolumn{4}{|c|}{ Diet } & \multirow{2}{*}{ P-value } \\
\hline & Whole corn grain & Ground corn & Citrus pulp & Steam-flaked corn & \\
\hline Dry matter intake $(\mathrm{kg} / \mathrm{d})$ & $6.82(0.21) b$ & $9.50(0.19) \mathrm{a}$ & $9.40(0.12) \mathrm{a}$ & $9.73(0.12) \mathrm{a}$ & 0.001 \\
\hline Initial weight $(\mathrm{kg})$ & $342(5.61)$ & $357(4.64)$ & $358(5.83)$ & $361(5.42)$ & 0.123 \\
\hline Final weight (kg) & $425(10.33) b$ & $459(6.31) \mathrm{a}$ & $450(5.69) \mathrm{ab}$ & $468(6.68) \mathrm{a}$ & 0.024 \\
\hline Average daily gain (kg) & $1.22(0.11) \mathrm{c}$ & $1.57(0.08) a b$ & $1.41(0.06) \mathrm{bc}$ & $1.64(0.04) \mathrm{a}$ & 0.006 \\
\hline Carcass weight (kg) & $224(6.53)$ & $242(3.76)$ & $237(3.78)$ & $241(3.92)$ & 0.166 \\
\hline Carcass average daily gain $(\mathrm{kg})$ & $0.80(0.07)$ & $0.98(0.05)$ & $0.90(0.04)$ & $0.93(0.03)$ & 0.221 \\
\hline Carcass yield $(\%)$ & $52.8(0.48)$ & $52.7(0.34)$ & $52.7(0.28)$ & $51.5(0.29)$ & 0.066 \\
\hline
\end{tabular}

Different letters indicate $\mathrm{P}<0.05$ according to Tukey-Kramer's test.

Whole corn grain - diet consisting of whole-grain corn and commercial pelleted supplement; Ground corn - diet consisting of Pennisetum purpureum silage and ground corn grain as the main ingredient in concentrate; Citrus pulp - diet consisting of Pennisetum purpureum silage and citrus pulp as the main feed in concentrate; Steam-flaked corn - diet consisting of Pennisetum purpureum silage and steam-flaked corn as the main ingredient in concentrate.

Carcass weight - eviscerated hot carcass weight. 
$1.22 \mathrm{~kg}$, albeit without showing reduction in fat thickness and REA compared with the other treatments (Tables 2 and 3). These results indicate that the DMI in diets with high concentrate levels were sufficient to produce animals at slaughter with adequate carcass traits (Table 2). The final live weight and carcass weight differed among diets $(\mathrm{P}<0.05)$. The average daily gain in live weight of the whole corn grain-based diet was different $(\mathrm{P}<0.05)$ from that of the other treatments (Table 2), which is partially explained by the lower final weight and carcass weight than in the animals fed steam-flaked corn- and ground cornbased diets.

Mandarino et al. (2013) reported ADG and dry matter daily intake of $1.25 \mathrm{~kg}$ and $8.52 \mathrm{~kg}(1.79 \% \mathrm{LW})$, respectively, when studying Nellore and Nellore $\times$ Brahman animals given a whole corn grain-based diet (corn grain:pellet ratio - 85:15\%), with $482.14 \mathrm{~kg}$ live weight at slaughter and a 96-day feedlot period, which are similar results to those obtained in this study. These results suggest that whole corn grain-based diets may be recommended for finishing Bos indicus animals, with similar gains to those obtained in the present study.

There was no treatment effect (diet) on carcass yield (CY) $(\mathrm{P}>0.05)$ (Table 2). Because the animals started the experiment with similar initial body weight and nutrient intake in relation to body weight $(0.28 \pm 0.03$ and $1.6 \pm 0.1 \%$ of body weight (BW) for $\mathrm{CP}$ and TDN, respectively), similar CADG and CY were expected.

The carcass yield values observed were lower than the $57.0 \%$ reported by Cruz et al. (2004) in a study with a group of animals with an average live weight of $400 \mathrm{~kg}$, an average age at slaughter of 17.5 months, and 150 days in the feedlot. Freitas et al. (2008) observed a value of $54.4 \%$, similar to that found in the present study $(52.0 \%)$, with 100 days in the feedlot, in animals slaughtered at 22 months of age with $395 \mathrm{~kg} \mathrm{LW}$. The animals in the present study remained in the feedlot for 85 days after 32 months of age, with an average live weight at slaughter of approximately $450 \mathrm{~kg}$. The yield differences between these studies may be explained by the longer feedlot period reported by Cruz et al. (2004).

The CADG was similar among treatments $(\mathrm{P}>0.05)$. Despite the smaller ADG in live weight for Whole corn grain when the carcass gain was evaluated in relation to Ground corn and Steam-flaked corn $(\mathrm{P}<0.05)$, this treatment produced the same response for CADG $(\mathrm{P}>0.05)$. This observation may be explained by the smaller amount of gastrointestinal contents and lower gastrointestinal tract weight than in the animals fed diets with higher roughage ratios (Silva et al., 2002). Furthermore, fat deposition may have occurred earlier in the treatments with the whole corn grain-based diets, which produced a lower carcass yield, despite the lower carcass weight compared with the diets with roughage, ground corn, and steam-flaked corn. Initial body weight and carcass weight were not affected by diets $(\mathrm{P}>0.05)$.

No dietary effect was observed on forequarter, hindquarter, or spare ribs (Table 3 ). The average fat thickness of the animals in all treatments was approximately $5 \mathrm{~mm}$ (4.97 mm), as suggested by Freitas et al. (2001). This result indicates that the nutritional management strategy used was sufficient in terms of carcass quality. Euclides Filho et al. (2003) reported that Nellore animals reach 5-mm fat thickness when they achieve a live body weight of 480 to $490 \mathrm{~kg}$, which are higher values than those found in the present study (Table 2). Differences in genetic constitution between animals of the same breed may also affect the level of carcass fat thickness as a function of body weight; that is, early-maturing animals show greater carcass fat thickness (Costa et al., 2002). Furthermore, the energy levels in the diet may explain the difference in these results, as reported by Euclides Filho et al. (2003), who worked with 50\% concentrate in the diet against a minimum of $62 \%$ in this study.

Ribeiro et al. (2008) recorded an average fat thickness of $5.5 \mathrm{~mm}$ in Nellore bullocks with live weight and average

Table 3 - Predicted means and standard error of the means (in parentheses) for forequarter, hindquarter, and spire ribs yields, fat thickness, and rib eye area in Nellore bulls

\begin{tabular}{|c|c|c|c|c|c|}
\hline \multirow{2}{*}{ Treatment/Variable } & \multicolumn{4}{|c|}{ Diet } & \multirow{2}{*}{ P-value } \\
\hline & Whole corn grain & Ground corn & Citrus pulp & Steam-flaked corn & \\
\hline Forequarter yield (\%) & $39.2(0.33)$ & $38.8(0.37)$ & $38.9(0.39)$ & $39.1(0.26)$ & 0.811 \\
\hline Hindquarter yield (\%) & $47(0.26)$ & $47.2(0.27)$ & $47(0.28)$ & $46.1(0.32)$ & 0.132 \\
\hline Spare ribs yield $(\%)$ & $11.6(0.18)$ & $11.9(0.28)$ & $11.8(0.42)$ & $12.3(0.12)$ & 0.082 \\
\hline Fat thickness (mm) & $4.75(0.49)$ & $5.62(0.6)$ & $4.5(0.63)$ & $5(0.46)$ & 0.596 \\
\hline Rib eye area $\left(\mathrm{cm}^{2}\right)$ & $73.2(3.7)$ & $73.3(2.81)$ & $75.6(3.04)$ & $76.8(2.69)$ & 0.786 \\
\hline Rib eye area, $\mathrm{cm}^{2} / \mathrm{kg} \mathrm{CCW}$ & $0.316(0.01)$ & $0.312(0.01)$ & $0.32(0.02)$ & $0.321(0.01)$ & 0.966 \\
\hline
\end{tabular}

Whole corn grain - diet consisting of whole-grain corn and commercial pelleted supplement; Ground corn - diet consisting of Pennisetum purpureum silage and ground corn grain as the main ingredient in concentrate; Citrus pulp - diet consisting of Pennisetum purpureum silage and citrus pulp as the main feed in concentrate; Steam-flaked corn - diet consisting of Pennisetum purpureum silage and steam-flaked corn as the main ingredient in concentrate.

$\mathrm{CCW}$ - cold carcass weight. 
age at slaughter of $474 \mathrm{~kg}$ and 36 months, respectively. The result from the present experiment with bulls regarding this trait was similar to that of bullocks.

Cruz et al. (2004) reported an average REA value similar to that reported in the present study, which was $68.91 \mathrm{~cm}^{2}$, while Freitas et al. (2008) reported lower values (61.23 $\times$ $74.71 \mathrm{~cm}^{2}$ ). This result suggests that a heavier slaughter weight is related to an increase in REA because in the latter study the average live weight and age were $400 \mathrm{~kg}$ and 22 months, respectively. However, Cruz et al. (2004) found no body weight effect on REA when assessing this trait in Nellore animals slaughtered with three different body weights (380, 410, and $440 \mathrm{~kg} \mathrm{LW})$. Therefore, other factors may be involved in the response of this variable. The dietary levels of concentrate may have affected the REA values observed in the present study, because Freitas et al. (2008) tested diets with $40 \%$ concentrate, Cruz et al. (2004) used $50 \%$, and the present study tested a minimum of $62 \%$ dietary concentrate.

The results regarding REA and fat thickness indicate that the feed management applied in this study aimed at carcass quality was efficient in all the treatments tested. The carcass fat depth is important for avoiding rapid fluctuations in the carcass temperature in the cold chamber and to prevent browning and muscle dryness (Dubeski et al., 1997; Euclides Filho et al., 2003), and the REA is a key predictor of the muscle tissue (meat) yield of the carcass (Goodall and Schmutz, 2007; Ribeiro et al., 2008).

Cooking time and evaporation, drip, thawing, and total weight losses, expressed as percentage of beef strip steak, and shear force did not differ $(\mathrm{P}>0.05)$ among the tested diets (Table 4). Menezes et al. (2006) reported average cooking loss values of approximately $23 \%$ for crossbred Bos indicus animals fed a diet with approximately $48 \%$ concentrate. Ribeiro et al. (2008) observed average values of $29.9 \%$ when studying Nellore bullocks. The latter authors reported results similar to this study $(26.82 \%)$. These results suggest that castration and the dietary levels of concentrate affect cooking losses, which may be explained by the fact that the dietary energy level and castration increase adipose tissue deposition on the carcass (Euclides Filho et al., 2003), and there is a positive relationship between cooking losses and carcass fat levels (Menezes et al., 2006).

The observed lack of dietary effects on cooking losses (Table 4) and carcass fat depth (Table 3) corroborate the results reported in the literature. Considering that there was no treatment effect on the carcass fat depth, no treatment effect on cooking losses would occur either because this type of loss is associated with marbling and intramuscular fat, which are deposited on the carcass after superficial fat deposition (Costa et al., 2002; Menezes et al., 2006).

Liquid losses (by evaporation) during cooking are negatively associated with meat juiciness during tasting $(\mathrm{r}=-0.34 ; \mathrm{P}=0.09)$, indicating that liquid losses reduce meat juiciness. Conversely, greater drip loss, which is associated with greater marbling fat on the carcass, is positively correlated with meat juiciness (Costa et al., 2002). These results suggest that the feeding strategies adopted in the present study may have produced similar meat quality among the treatments.

No treatment effect was observed for thawing losses or shear force (Table 4). Costa et al. (2002) and Arboitte et al. (2004) reported 9.51 and $9.60 \%$ thawing losses from animals with average slaughter weights of 430 and $467 \mathrm{~kg}$ LW, respectively, at approximate average ages of 13.5 and 26 months. They also recorded average shear force values of 3.99 and $3.79 \mathrm{kgf}$, respectively. These results are in disagreement with the present experiment $(3.88 \%$ and $5.85 \mathrm{kgf}$ ). However, age, breed, and category (castrated $\times$ uncastrated) may contribute to such differences; those authors studied Red Angus and Nellore $\times$ Charolais bullocks, respectively. Bos taurus animals have been reported to show a higher marbling degree than Bos indicus animals (Euclides Filho et al., 2003), even as castrated animals. These hypotheses may explain the lower shear force values reported in the studies above compared with the values

Table 4 - Predicted means and standard error of the means (in parentheses) for losses during the cooking and thawing processes and shear force of beef strip steak from Nellore bulls

\begin{tabular}{|c|c|c|c|c|c|}
\hline \multirow{2}{*}{ Treatment/Variable } & \multicolumn{4}{|c|}{ Diet } & \multirow{2}{*}{ P-value } \\
\hline & Whole corn grain & Ground corn & Citrus pulp & Steam-flaked corn & \\
\hline Cooking time (min) & $36.5(1.43)$ & $37.5(1.4)$ & $39(4.83)$ & $35.9(4.24)$ & 0.918 \\
\hline Evaporation losses (\%) & $23.6(1.08)$ & $22.6(0.52)$ & $22(1.54)$ & $23.1(0.93)$ & 0.782 \\
\hline Drip losses (\%) & $4.07(0.31)$ & $4.3(0.46)$ & $3.74(0.57)$ & $3.87(0.45)$ & 0.86 \\
\hline Total losses $(\%)$ & $27.6(0.95)$ & $26.9(0.59)$ & $25.7(1.88)$ & 27 (1.07) & 0.821 \\
\hline Thawing losses (\%) & $3.76(0.52)$ & $3.7(0.46)$ & $3.51(1.38)$ & $4.55(0.53)$ & 0.629 \\
\hline Shear force $(\mathrm{kgf})$ & $6.18(1.33)$ & $5.66(0.60)$ & $5.56(1.60)$ & $6.04(0.73)$ & 0.571 \\
\hline
\end{tabular}

Whole corn grain - diet consisting of whole-grain corn and commercial pelleted supplement; Ground corn - diet consisting of Pennisetum purpureum silage and ground corn grain as the main ingredient in concentrate; Citrus pulp - diet consisting of Pennisetum purpureum silage and citrus pulp as the main feed in concentrate; Steam-flaked corn - diet consisting of Pennisetum purpureum silage and steam-flaked corn as the main ingredient in concentrate. 
from this study, because marbling is positively (Costa et al., 2002) and age is negatively (Costa et al., 2005; Perry and Thompson, 2005) associated with meat tenderness.

Although the results from this study regarding fat depth and cooking losses are similar to Nellore bullocks, the thawing losses and shear force are at odds with the values of $10.5 \%$ and $14.83 \mathrm{kgf}$ recorded by Ribeiro et al. (2008), respectively, for animals slaughtered with an average live weight of $474 \mathrm{~kg}$, at 36 months of age. These results suggest that increased liquid losses from thawing imply a reduction of meat tenderness. The dietary level of concentrate may also affect the meat tenderness because the animals remained on a pasture regimen in the study by Ribeiro et al. (2008).

Restle et al. (1996) stated that meat packers pay better prices for heavier animals, given their greater carcass yield, resulting in larger meat cuts, preferred by both domestic and foreign markets. Increased body weight has been reported to cause meat tenderness loss (Restle et al., 1999; Costa et al., 2002; Vaz et al., 2002). However, the increased LW of the animals fed diets based on steamflaked corn and ground corn in relation to whole corn grain were insufficient to promote changes in meat tenderness, considering the shear force. The lack of treatment effects on the other traits, including carcass fat depth, cooking losses, and thawing losses, may explain the similarity $(\mathrm{P}>0.05)$ observed in shear force among the treatments of this study.

\section{Conclusions}

Based on the quantitative and qualitative analysis of this study, there is no restriction for the adoption of any of the tested diets in feedlots with Nellore bulls, and the evaluated energy sources may be used to replace ground corn grain.

\section{Acknowledgments}

The authors acknowledge the experimental farm of Pontifícia Universidade Católica de Minas Gerais (PUCMG), where the field experiments of the study were conducted, and Coordenação de Aperfeiçoamento de Pessoal de Nível Superior (CAPES), Fundação de Amparo à Pesquisa do Estado de Minas Gerais (FAPEMIG), Conselho Nacional de Desenvolvimento Científico e Tecnológico (CNPq), and Instituto Nacional de Ciência e Tecnologia de Ciência Animal (INCT-CA) for funding this study.

\section{References}

AOAC - Association of Official Analytical Chemists. 1990. Official methods of analysis. 15th ed. AOAC, Arlington, VA.

Arboitte, M. Z.; Restle, J.; Alves Filho, D. C.; Brondani, I. L.; Pacheco, P. S.; Menezes, L. F. G. D. and Perottoni, J. 2004. Composição física da carcaça, qualidade da carne e conteúdo de colesterol no músculo Longissimus dorsi de novilhos $5 / 8$ Nelore - 3/8 Charolês terminados em confinamento e abatidos em diferentes estádios de maturidade. Revista Brasileira de Zootecnia 33:959-968.

Boggs, D. L. and Merkel, R. A. 1979. Beef carcass evaluation, grading and pricing. p.75-98. In: Live animal carcass evaluation and selection manual. Boggs, D. L. and Merkel, R. A., eds. Kendall/Hunt Publishing Company, Dubuque, Iowa.

Buttrey, E. K.; McCollum, F. T.; Jenkins, K. H.; Patterson, J. M.; Clark, B. E.; Luebbe, M. K.; Lawrence, T. E. and MacDonald, J. C. 2012. Use of dried distillers grains throughout a beef production system: Effects on stocker and finishing performance, carcass characteristics, and fatty acid composition of beef. Journal of Animal Science 90:2381-2393.

Capelle, E. R.; Valadares Filho, S. C.; Silva, J. F. C. and Cecon, P. R. 2001. Estimativas do valor energético a partir de características químicas e bromatológicas dos alimentos. Revista Brasileira de Zootecnia 30:1837-1856.

Costa, E. C. D.; Restle, J.; Brondani, I. L.; Perottoni, J.; Faturi, C. and Menezes, L. G. D. 2002. Composição física da carcaça, qualidade da carne e conteúdo de colesterol no músculo Longissimus dorsi de novilhos Red Angus Superprecoces, terminados em confinamento a abatidos com diferentes pesos. Revista Brasileira de Zootecnia 31:417-428.

Costa, M. A. L.; Valadares Filho, S. C.; Paulino, M. F.; Valadares, R. F. D.; Cecon, P. R.; Paulino, P. V. R.; Moraes, E. H. B. K. D. and Magalhães, K. A. 2005. Desempenho, digestibilidade e características de carcaça de novilhos zebuínos alimentados com dietas contendo diferentes níveis de concentrado. Revista Brasileira de Zootecnia 34:268-279.

Cruz, G. M. D.; Tullio, R. R.; Esteves, S. N.; Alencar, M. M. D. and Cordeiro, C. A. 2004. Peso de abate de machos não-castrados para produção do bovino jovem. 2. Peso, idade e características da carcaça. Revista Brasileira de Zootecnia 33:646-657.

Dubeski, P. L.; Aalhus, J. L.; Jones, S. D. M.; Robertson, W. M. and Dyck, R. S. 1997. Meat quality of heifers fattened to heavy weights to enhance marbling. Canadian Journal of Animal Science 77:635-643.

Euclides Filho, K.; Figueiredo, G. R. D.; Euclides, V. P. B.; Silva, L. O. C. D.; Rocco, V.; Barbosa, R. A. and Junqueira, C. E. 2003. Desempenho de diferentes grupos genéticos de bovinos de corte em confinamento. Revista Brasileira de Zootecnia 32:1114-1122.

Freitas, A. K. D.; Restle, J.; Pacheco, P. S.; Padua, J. T.; Lage, M. E.; Miyagi, E. S. and Silva, G. F. R. D. 2008. Características de carcaças de bovinos Nelore inteiros vs castrados em duas idades, terminados em confinamento. Revista Brasileira de Zootecnia 37:1055-1062.

Freitas, J. D. A.; Guerra, J. L. and Panetta, J. C. 2001. Características da tuberculose observada em búfalos abatidos para consumo: aspectos patológicos e identificação de micobactérias. Brazilian Journal of Veterinary Research and Animal Science 38:170-176.

Goodall, J. J. and Schmutz, S. M. 2007. IGF2 gene characterization and association with rib eye area in beef cattle. Animal Genetics $38: 154-161$.

Licitra, G.; Hernandez, T. M. and Van Soest, P. J. 1996. Standardization of procedures for nitrogen fractionation of ruminant feeds. Animal Feed Science and Technology 57:347-358. 
Mandarino, R. A.; Barbosa, F. A.; Cabral Filho, S. L. S.; Lobo, C. F.; Silva, I. S.; Oliveira, R. V.; Diogo, J. M. S. and Guimarães Júnior, R. 2013. Desempenho produtivo e econômico do confinamento de bovinos zebuínos alimentados com três dietas de alto grão. Arquivo Brasileiro de Medicina Veterinária e Zootecnia 65:1463-1471.

Marcondes, M. I.; Chizzotti, M. L.; Valadares Filho, S. D. C.; Giombelli, M. P.; Paulino, P. V. R. and Paulino, M. F. 2010. Exigências nutricionais de energia para bovinos de corte. p.85-111. In: Exigências nutricionais de zebuínos puros e cruzados BR - CORTE. 2.ed. Valadares Filho, S. C.; Marcondes, M. I.; Chizzotti, M. L. and Paulino, P. V. R., eds. UFV/DZO, Viçosa, MG.

Mehrez, A.Z. and Ørskov, E. R. 1977. A study of the artificial fiber bag technique for determining the digestibility of feeds in the rumen. Journal of Agricultural Science 88:645-665.

Menezes, L. F. G. D.; Kozloski, G. V.; Restle, J.; Deschamps, F. C.; Brondani, I. L.; Santos, A. P. and Fiamoncini, J. 2006. Perfil de ácidos graxos de cadeia longa e qualidade da carne de novilhos terminados em confinamento com diferentes níveis de monenzina sódica na dieta. Ciência Rural 36:186-190.

Mertens, D. R. 1994. Regulation of forage intake. p.450-493. In: Forage quality, evaluation and utilization. Fahey JR., G. C., ed. American Society of Agronomy, Madison.

NRC - National Research Council. 2001. Nutrient requirements of dairy cattle. 7th ed. National Academic Press, Washington, DC.

Passini, R.; Borgatti, L. M. O.; Ferreira, F. A. and Rodrigues, P. H. M. 2004. Degradabilidade no rúmen bovino de grãos de milho processados de diferentes formas. Pesquisa Agropecuária Brasileira 39:271-276.

Paulino, P. V. R.; Oliveira, T. S.; Gionbeli, M. P. and GalloRev, S. B. 2013. Dietas sem forragem para terminação de animais ruminantes. Revista Científica de Produção Animal 15:161-172.

Perry, D. and Thompson, J. M. 2005. The effect of growth rate during backgrounding and finishing on meat quality traits in beef cattle. Meat Science 69:691-702.

Pinheiro, J.; Bates, D.; DebRoy, S.; Sarkar, D. and R Core Team. 2013. nlme: Linear and Nonlinear Mixed Effects Models. R Package Version 3:1-110.

R Core Team. 2015. R: A language and environment for statistical computing. R Foundation for Statistical Computing, Vienna, Austria.
Restle, J.; Grassi, C. and Feijó, G. L. D. 1996. Desenvolvimento e rendimento de carcaça de bovinos inteiros ou submetidos a duas formas de castração, em condições de pastagem. Revista da Sociedade Brasileira de Zootecnia 25:324-333.

Restle, J.; Polli, V. A.; Alves Filho, D. C.; Senna, D. B. D.; Vaz, R. Z.; Bernardes, R. A. C. and Silva, J. H. S. D. 1999. Desenvolvimento de bovinos de corte de diferentes grupos genéticos desmamados aos 3 ou 7 meses de idade. Revista Brasileira de Zootecnia 28:1023-1030.

Ribeiro, E. L. D. A.; Hernandez, J. A.; Zanella, E. L.; Mizubuti, I. Y.; Silva, L. D. D. F. D. and Reeves, J. J. 2008. Desempenho e características de carcaça de bovinos de diferentes grupos genéticos. Revista Brasileira de Zootecnia 37:1669-1673.

Sakamoto, L. S.; Mercadante, M. E. Z.; Bonilha, S. F. M.; Branco, R. H.; Bonilha, E. F. M. and Magnani, E. 2014. Prediction of retail beef yield and fat content from live animal and carcass measurements in Nellore cattle. Journal of Animal Science 92:5230-5238.

Silva, F. F.; Valadares Filho, S. C.; Ítavo, L. C. V.; Veloso, C. M.; Paulino, M. F.; Valadares, R. F. D.; Cecon, P. R.; Silva, P. A. and Galvão, R. M. 2002. Consumo, desempenho, características de carcaça e biometria do trato gastrintestinal e dos órgãos internos de novilhos Nelore recebendo dietas com diferentes níveis de concentrado e proteína. Revista Brasileira de Zootecnia 31:1849-1864.

Theurer, C. B.; Huber, J. T.; Delgado-Elorduy, A. and Wanderley, R. 1999. Invited review: summary of steam-flaking corn or sorghum grain for lactating dairy cows. Journal of Dairy Science 82:1950-1959.

Van Soest, P. J.; Robertson, J. B. and Lewis, B. A. 1991. Methods for dietary fiber, neutral detergent fiber, and nonstarch polysaccharides in relation to animal nutrition. Journal of Animal Science 74:3583-3597.

Vaz, F. N.; Restle, J.; Quadros, A. R. B.; Pascoal, L. L.; Sanchez, L. M. B.; Rosa, J. R. P. and Menezes, L. F. G. D. 2002. Características da carcaça e da carne de novilhos e de vacas de descarte Hereford, terminados em confinamento. Revista Brasileira de Zootecnia 31:1501-1510.

Yokoo, M.; Araujo, F.; Sainz, R. D. and Rocha, G. 2003. Comparison among commercial beef cuts in Brazil, Australia and the United States. p.189-191. In: Proceedings of the 49th International Congress Meat Science Technology, Campinas; Brazilian International Congress Meat Science Technology, Campinas, Brazil. 